\title{
Importance of Company Reputation and its Customer-Oriented Culture for Strengthening of Relationships with Customers on Industrial Market with Chemical Products
}

\author{
Hana Lostakova ${ }^{1}$, Iva Stejskalova ${ }^{2},{ }^{1,2}$ University of Pardubice
}

\begin{abstract}
The aim of this paper is to explain the nature of customer-oriented business culture and its various components and to summarize the results of quantitative marketing research among managers of selected chemical industry businesses in the Czech Republic focused on mapping of what is their perception of the usefulness of various aspects of the customer-oriented corporate culture, image and goodwill of the company for strengthening business relationships with customers and how they perceive their current level in their company and business units. This quantitative research was carried out using the method of personal interviews in April 2013. The survey was accomplished in four chemical business units. The obtained data were processed using statistical software IBM SPSS Statistics and by synthesis of the obtained findings. The research showed that the customer-oriented corporate culture and the perceived reputation of the company is very important and beneficial for strengthening the relationship with customers in chemical industry.
\end{abstract}

Keywords - Chemical industry, company reputation, customeroriented culture, strengthening relationships with customers.

\section{INTRODUCTION}

The concept of corporate reputation draws academic attention from the management, economics, sociology, and marketing areas [1].

Corporate reputation is one of the most valuable assets associated with the products and services of the company. They simplify decision-making for the customers, reduce their risk and create their expectations. This makes these aspects of the supply invaluable [2].

According to the resource-based view of the firm, corporate reputation can be considered to be a valuable strategic resource that contributes to a firm's sustainable competitive advantage [3] [4]. The formation of a good reputation is a long-term process inside an organization, thus it is an intangible asset that is difficult for competitors to imitate.

While some studies document a positive relationship between corporate reputation and financial performance [5], [6] and try to explain the underlying mechanisms and consequences of corporate reputation [7], the existing research in the marketing literature says little about whether corporate reputation can contribute to strengthening of relationships with customers.

In our opinion, maintaining and enhancing relationships with customers during the recession requires deepening of customeroriented culture of cooperation of various departments of the company, which will enhance the company image and goodwill among its customers.

\section{AIM AND METHODOLOGY}

The aim of this paper is to explain the nature of corporate reputation and customer-oriented business culture and their various components, and summarize the results of quantitative marketing research among managers of selected chemical industry businesses in the Czech Republic focused on mapping of what is their perception of the usefulness of various aspects of the corporate reputation and customeroriented corporate culture for strengthening business relationship with customers and how they perceive their current level in their company and business units. This quantitative research was carried out using the method of personal interviews in April 2013. The quantitative research was conducted in selected chemical companies in the Czech Republic in SBUs ${ }^{1}$ producing industrial explosives, organic semi-finished products and specialities, organic dyes and pigments and nitrocellulose, among 47 managers of these SBUs working in the top, middle and first line management, namely, among directors of the SBUs, strategic development managers, research and development managers, sales managers, sales representatives, production managers and technologists, quality managers, purchase managers and managers of consulting and application services. This research was conducted through the method of personal interviews using a semi-structured questionnaire in which managers rated the usefulness and the actual level of individual aspects of company reputation and customer-oriented corporate culture that could strengthen the relationship between producers and consumers. The respondents were those managers and workers of the chemical business units that are part of the internal value network of SBUs, are in direct contact with customers and directly participate in creating and increasing the value to them and the value of relationships.

With the exception of the open-ended questions, evaluation of the research was carried out using the statistical program

${ }^{1} \mathrm{SBU}$ is an organizational unit of company that is directed by one manager, that is oriented on producing and selling of certain product line, satisfying certain needs and wants of customers and has its own competitors on the market. 
IBM SPSS Statistics, version 21 and by synthesis of the obtained findings.

\section{CORPORATE REPUTATION AND ITS ROLE IN STRENGTHENING CUSTOMER RELATIONSHIPS}

In the not too distant past, corporate reputation and image were rather vague concepts that were perceived to be, at best, of peripheral concern to senior management. Typically, they were seen as the province of the public relations department and design consultants. Today, however, an increasing number of astute executives recognize them as critical corporate asset directly linked to competitive success. These factors have always conferred strategic leverage. But the pervasive blurring of boundaries between organizations and their stakeholders in today's business world has highlighted the need to strategically manage corporate reputation and image. Moreover, ongoing discrete trends such as globalization, merger mania, deregulation and privatisation, and the acceleration of product life cycles has created a sense of urgency for many firms [8].

Corporate image is the mental picture of the company held by its audiences - that comes to mind when one sees or hears the corporate name or sees its logo. Corporate reputation is a related concept. It connotes the estimation of the company by its constituents. Is it held in high or low repute or somewhere in between?

In general, these conceptual components are managed with two primary objectives in mind. The first is to create the "intended image" in the minds of the company's principal constituents. Commonly, this means creating wide-spread name recognition among the company's target stakeholders along with immediate identification of the firm's business field and principal products. The second objective in managing the process is to create a favorable reputation in the minds of the important stakeholders. In general, a salient corporate image can be created more quickly and easily than a sterling reputation. A strong image can be built through a coordinated image-building campaign that encompasses a formal communication system-name, logo, signage, corporate advertising, and public relations. A favorable reputation, on the other hand, requires more than just an effective communication effort; it requires a meritorious identity that can only be molded through consistent performance, usually over many years [9]. The company reputation is a key aspect of the customer relationships management [10]. It is the only way to create strong relationships among all business partners and other stakeholders in the value network [11], [12].

If the company reputation plays this key role, it needs to be built on customer-oriented culture, developed not only within the company, but throughout the value network, as an important component in strengthening customer relationships and increasing customer commitment [13], [14].

The management of the companies realizes the need to build the company reputation and the customer-oriented culture as a basis for strengthening relationships with stakeholders, especially with customers. It is therefore necessary to realize how important the various aspects of the company reputation are to the stakeholders and how beneficial they are in strengthening customer relationships.

\section{RESUlTS AND DisCUSSIONS OF PRIMARY RESEARCH}

The research objective was to find out the beneficial effect and the actual level of individual components of company reputation and partial aspects of customer-oriented culture in the enterprise-customer interconnection from the point of view of managers in chemical production enterprises who come into contact with the customers and who participate in making offers and increasing the value for them.

In preparation of the research, based on the literature research and in-depth interviews among managers in chemical industry, hypotheses were built that in the chemical products market it is especially these aspects of the company reputation and customer-oriented culture that are very beneficial for strengthening the relationship between business partners.

1 . The company reputation among customers.

- Overall quality of the company and a very good reputation in the industry.

- Long tradition of the company as a manufacturer of products.

- Long-term positive customer experience with the company.

- High quality of products in accordance with customer needs.

- High technical standard and progressiveness of products.

- Consistent standard of product quality parameters in all deliveries.

- High standard mastery of technological processes in the company.

- Quality of the customer base - serving the major players in the industry.

2. Customer-oriented corporate culture in the company.

- Customer-oriented democratic (partnership) management style in the company.

- High level of mutual information sharing and cooperation between internal units in serving customers.

- High degree of cooperation and cohesion of the company with all external stakeholders in the value network in serving customers.

- System and rules of customer contacts developed in the company for all the units that come into contact with customers.

- Senior management participating in negotiations with customers.

- Functional system to process and share information from customer contacts with those company units that need it.

In a subsequent quantitative research, the managers of the companies surveyed rated the benefits and the actual level of the individual aspects of the company reputation and corporate culture for strengthening relations on multi item scales. All scales were 7-point ones, from 1 - extremely low to 7 - extremely high.

Given the number of researched SBUs and their managers, we cannot generalize the results of the research on the whole chemical industry. The results have confirmed some hypotheses, 
while not confirming others, and led to the selection of the factors leading to stronger relationships with customers.

\section{A. The Benefits and the Actual Level of the Company Reputation among Customers}

On average, the chemical business managers perceive the benefits of the aspects of the company reputation among customers for strengthening mutual relations on the scale of $1-7$ with the value between 5.3 and 6.1, i.e., mainly "very beneficial". Also, they rated their real level on the scale of $1-7$ with 5.0 to 5.8 , using the words "rather high" or in one case "very high" (Table I), (Fig. 1).

TABLE I

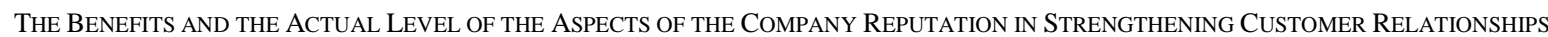

\begin{tabular}{|c|c|c|c|c|c|c|}
\hline \multirow[t]{2}{*}{ COMPANY REPUTATION ASPECTS } & \multicolumn{3}{|c|}{ BENEFICIAL EFFECT } & \multicolumn{3}{|c|}{ ACTUAL LEVEL } \\
\hline & $\mathrm{N}$ & $M^{*}$ & $\mathrm{SD}^{*}$ & $\mathrm{~N}$ & $\mathrm{M}^{*}$ & SD \\
\hline Overall quality of the company and a very good reputation in the industry & 45 & 5.5 & 1.0 & 44 & 5.1 & 1.1 \\
\hline Long tradition of the company as a manufacturer of products & 45 & 5.3 & 1.3 & 44 & 5.8 & 1.2 \\
\hline Long-term positive customer experience with the company & 45 & 6.0 & 1.2 & 45 & 5.4 & 1.1 \\
\hline High quality of products in accordance with customer needs & 43 & 6.1 & 1.1 & 44 & 5.5 & 1.2 \\
\hline High technical standard and progressiveness of products & 44 & 5.7 & 1.2 & 44 & 5.2 & 1.3 \\
\hline Consistent standard of product quality parameters in all deliveries & 44 & 6.0 & 1.1 & 44 & 5.3 & 1.2 \\
\hline High standard mastery of technological processes in the company & 43 & 5.3 & 1.1 & 45 & 5.2 & 1.2 \\
\hline Quality of the customer base - serving the major players in the industry & 43 & 5.5 & 1.2 & 45 & 5.0 & 1.3 \\
\hline Valid N (listwise) & 40 & & & & & \\
\hline
\end{tabular}

Notes: N - Number; M - Mean; SD - Std. Deviation; * The scale used from 1 - extremely low to 7 - extremely high.

Source: Self-processed

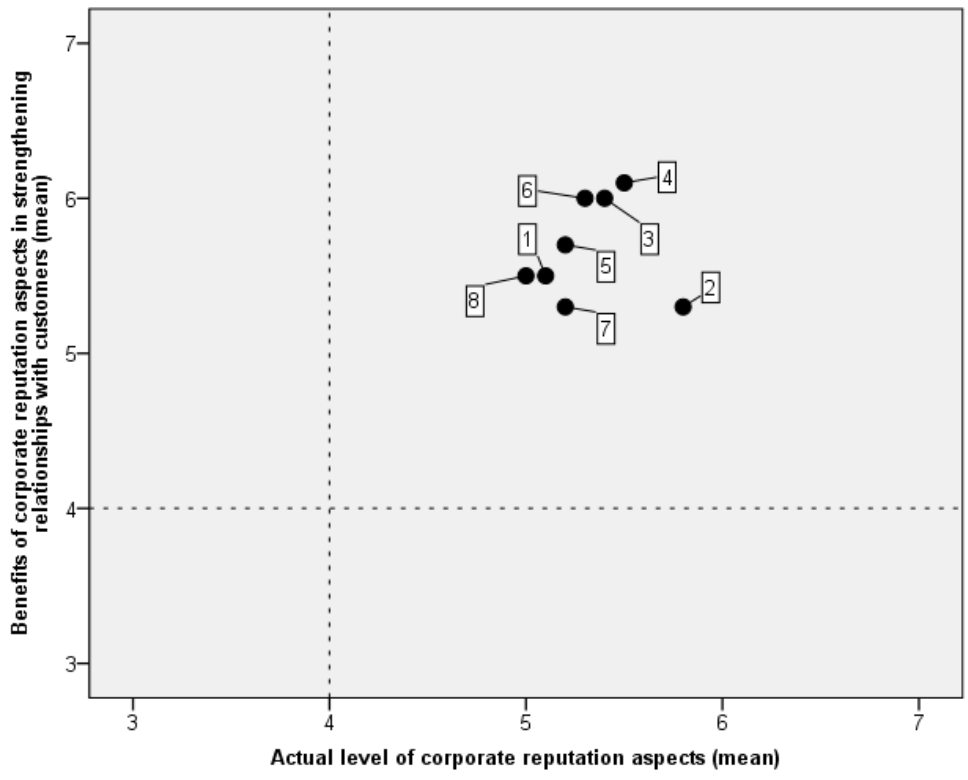

Legend:

1 - Overall quality of the company and very good reputation in the industry.

2 - Long tradition of the company as a manufacturer of products.

3 - Long-term positive customer experience with the company

4 - High quality of products in accordance with customer needs

5 - High technical standard and progressiveness of products

6 - Consistent standard of product quality parameters in all deliveries

7 - High standard mastery of technological processes in the company

8 - Quality of the customer base - serving the major players in the industry

Notes:

The scale used from 1 - extremely low to 7 - extremely high.

Fig. 1. The Benefits and the Actual Level of the Aspects of the Company Reputation in Strengthening Customer Relationships. Source: Self-processed

The managers of the chemical SBUs surveyed are aware that highly beneficial for strengthening customer relationships is the overall quality of the company, its very good reputation in the industry, the reputation of a supplier of high quality products that are progressive, have a high technical standard, are in accordance with customer needs and have a consistent standard of product quality parameters in all deliveries. They consider other aspects of the company reputation to be rather beneficial.

Chí-Square tests have showed (Pearson Chí-Square value of $65.511, d f=35, p=0.01$ ) that the opinions on the benefits of the overall quality of the company and its very good reputation in the industry for strengthening customer relationships are significantly different among managers from different units of the company when the top managers, and the managers from the units of strategic development, sales, customer service and purchase consider them very beneficial. On the contrary, research and development managers and quality managers maintain contradictory views on the issue when a half perceives them as rather beneficial and the other half as rather unbeneficial.

Differences in the opinions were also in the view of managers of various SBUs on the benefits of the reputation of a company with a high level of mastery of technological 
$2014 / 26$

processes in the company (Pearson Chí-Square value of 21.675, $d f=12, p=0.041$ ) as this aspect is very beneficial for strengthening the relationship in SBUs of industrial explosives, nitrocellulose and organic semi-finished products and specialties, while managers of the dyes and pigments SBU consider them only as rather beneficial.

Also, the perception of the benefit aspect of reputation concerning the quality level of the customer base, when the company serves the leading players in the field, for strengthening customer relationships were significantly different (Pearson Chí-Square value of 34.154, $d f=20$, $p=0.025$ ) among managers with different time of work in the company. It has been proved that the more senior the manager,

the more beneficial they consider this aspect of the company reputation for strengthening customer relationships. Even those managing a unit for more than 15 years consider this aspect of the company reputation to be very beneficial.

TABLE II

The Benefits AND THE ACTUAL LEVEl OF ASPECTS OF THE CUSTOMER-ORIENTED CORPORATE CULTURE IN THE COMPANY IN STRENGTHENING CUSTOMER RELATIONSHIPS

\begin{tabular}{|c|c|c|c|c|c|c|}
\hline \multirow[t]{2}{*}{ CuSTOMER-ORIENTED CORPORATE CULTURE ASPECTS } & \multicolumn{3}{|c|}{ BENEFICIAL EFFECT } & \multicolumn{3}{|c|}{ ACTUAL LEVEL } \\
\hline & $\mathrm{N}$ & $M^{*}$ & SD & $\mathrm{N}$ & $\mathrm{M}^{*}$ & SD \\
\hline Customer-oriented democratic (partnership) management style in the company & 41 & 5.0 & 1.3 & 40 & 4.5 & 1.1 \\
\hline High level of mutual information sharing and cooperation between internal units in serving customers & 43 & 5.3 & 1.1 & 43 & 4.5 & 1.2 \\
\hline $\begin{array}{l}\text { High degree of cooperation and cohesion of the company with all external stakeholders in the value } \\
\text { network in serving customers }\end{array}$ & 43 & 5.2 & 1.2 & 42 & 4.5 & 1.3 \\
\hline $\begin{array}{l}\text { System and rules of customer contacts developed in the company for all the units that come into contact } \\
\text { with customers }\end{array}$ & 43 & 5.1 & 1.1 & 43 & 4.6 & 1.2 \\
\hline Senior management participating in negotiations with customers & 43 & 5.1 & 1.4 & 43 & 4.8 & 1.3 \\
\hline $\begin{array}{l}\text { Functional system to process and share information from customer contacts with those company units that } \\
\text { need it }\end{array}$ & 43 & 5.4 & 1.0 & 44 & 4.7 & 1.2 \\
\hline Valid N (listwise) & 40 & & & 39 & & \\
\hline
\end{tabular}

Notes: N - Number; M - Mean; SD - Std. Deviation; * The scale used from 1 - extremely low to 7 - extremely high.

Source: Self-processed

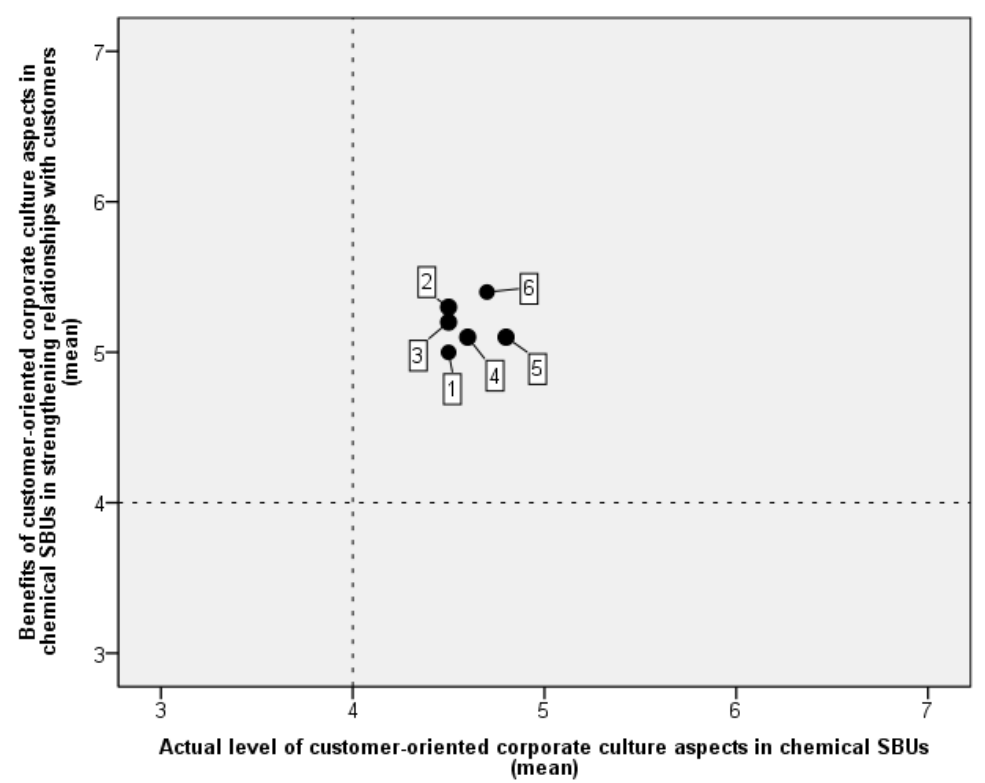

Legend:

1 - Customer-oriented democratic (partnership) management style in the company

2 - High level of mutual information sharing and cooperation between internal units in serving customers

3 - High degree of cooperation and cohesion of the company with all external stakeholders in the value network in serving customers

4 - System and rules of customer contacts developed in the company for all the units that come into contact with customers

5 - Senior management participating in negotiations with customers

6 - Functional system to process and share information from customer contacts with those company units that need it.

Notes:

The scale used from 1 - extremely low to 7 - extremely high.

Fig. 2. The Benefits and the Actual Level of Aspects of the Customer-Oriented Corporate Culture in the Chemical SBUs in Strengthening Relationships with Customers. Source: Self-processed 
The research results have not confirmed the hypothesis about the great benefits of the customer-oriented corporate culture for strengthening customer relationships. The ChiSquare tests have not revealed any differences between the perception of its benefits among managers of the various SBUs, types of units, positions in the management hierarchy, age, seniority and gender. As for opinions, therefore, the managers exceptionally share the same view. The subsequent qualitative research has revealed that the managers consider the customer-oriented culture of the company to be such a matter of course that they cannot even imagine that companies especially in times of recession would be managed on the basis of a market approach concept other than the marketing one.
The actual level of the customer-oriented corporate culture was perceived by the managers interviewed as rather high, which confirms the previous claim. It is understandable that there is always something in any company to improve in terms of customer care, so the assessment "rather higher level" of the customer-oriented culture in the SBUs surveyed is realistic.

\section{B. Relations Between Benefits of Corporate Reputation Aspects and Aspects of the Customer-Oriented Corporate Culture for Strengthening Customer Relationships}

Mutual links among all studied aspects of the corporate reputation and the corporate customer-oriented culture in selected chemical product lines were described by Pearson bivariate correlation coefficients (see Table III).

TABLE III

PEARSON CORRELATION COEFFICIENT AMONG THE BENEFITS OF ASPECTS OF THE COMPANY REPUTATION

\begin{tabular}{|c|c|c|c|c|c|c|c|c|}
\hline $\begin{array}{c}\text { ASPECTS OF THE COMPANY } \\
\text { REPUTATION }\end{array}$ & A & B & C & D & E & $\mathrm{F}$ & G & $\mathrm{H}$ \\
\hline A & 1 & $.703^{* *}$ & $.491^{* *}$ & $.615^{* *}$ & $.518^{* *}$ & $.507^{* *}$ & $.552^{* *}$ & $.490^{* *}$ \\
\hline B & $.703^{* *}$ & 1 & $.604^{* *}$ & $.557^{* *}$ & $.631^{* * *}$ & $.545^{* *}$ & $.515^{* *}$ & $.642^{* *}$ \\
\hline $\mathrm{C}$ & $.491^{* *}$ & $.604^{* *}$ & 1 & $.760^{* *}$ & $.662^{* *}$ & $.707^{* *}$ & $.501^{* *}$ & $.658^{* *}$ \\
\hline $\mathrm{D}$ & $.615^{* *}$ & $.557^{* *}$ & $.760^{* *}$ & 1 & $.803^{* *}$ & $.865^{* *}$ & $.648^{* *}$ & $.614^{* *}$ \\
\hline $\mathrm{E}$ & $.518^{* *}$ & $.631^{* *}$ & $.662^{* *}$ & $.803^{* *}$ & 1 & $.760^{* *}$ & $.651^{* *}$ & $.684^{* *}$ \\
\hline $\mathrm{F}$ & $.507^{* *}$ & $.545^{* *}$ & $.707^{* *}$ & $.865^{* *}$ & $.760^{* *}$ & 1 & $.601^{* *}$ & $.622^{* * *}$ \\
\hline $\mathrm{G}$ & $.552^{* *}$ & $.515^{* *}$ & $.501^{* *}$ & $.648^{* *}$ & $.651^{* *}$ & $.601^{* *}$ & 1 & $.443^{* *}$ \\
\hline $\mathrm{H}$ & $.490^{* *}$ & $.642^{* *}$ & $.658^{* *}$ & $.614^{* * *}$ & $.684^{* *}$ & $.622^{* *}$ & $.443^{* *}$ & 1 \\
\hline
\end{tabular}

Legend

A - Overall quality of the company and a very good reputation in the industry. B - Long tradition of the company as a manufacturer of products.

$\mathrm{C}$ - Long-term positive customer experience with the company.

D - High quality of products in accordance with customer needs.

A strong correlation has been confirmed among all aspects of the company reputation, indicating that the chemical industry companies should develop all the studied aspects of the company reputation in order to strengthen the relationships with customers.

Also, a positive correlation has been found among the benefits of the various aspects of the customer-oriented corporate culture for strengthening customer relationships, but not as strong as with the company reputation aspects (see Table IV). At the same time, the managers consider as beneficial the factors of the company customer orientation such as "a high level of mutual information sharing and cooperation between internal units in serving customers" and "a high degree of cooperation and cohesion of the company with all external stakeholders in the value network in serving customers" along with the system and rules of customer contacts developed in the company for all the units that come into contact with customers, thus a strong mutual cooperation in the value network and a functional system to process and share information from customer contacts with those company units that need it.
E - High technical standard and progressiveness of products.

$\mathrm{F}$ - Consistent standard of product quality parameters in all deliveries.

$\mathrm{G}$ - High standard mastery of technological processes in the company.

$\mathrm{H}$ - Quality of the customer base - serving the major players in the industry.

The factor analysis by extraction method Principal Component Analysis with Varimax rotation has revealed two main factors strengthening customer relationships, namely a comprehensively conceived reputation of the company and promotion of customer orientation in the company by the top management and SBU (see Table V).

In the opinion of the interviewed managers of chemical companies, the company reputation is dependent especially on the long tradition as a manufacturer of products, long-term positive customer experience with the company, the reputation of a manufacturer of high quality products in accordance with customer requirements, high technical quality and progressiveness of products and consistent standard of product quality parameters in all deliveries.

In their opinion, promoting customer orientation in the company requires a democratic (partnership) customer-oriented style of management in the company along with the participation of the top management in negotiations with customers.

At the same time, the managers consider as beneficial the factors of the company customer orientation such as "a high level of mutual information sharing and cooperation between 
TABLE IV

PEARSON CORRELATION COEFFICIENT AMONG THE BENEFITS OF THE ASPECTS OF THE CUSTOMER-ORIENTED CORPORATE CUlture

\begin{tabular}{|l|l|l|l|l|l|l|}
\hline \multicolumn{1}{|c|}{ ASPECTS OF THE CUSTOMER-ORIENTED CORPORATE CULTURE } & A & B & C & D & E & F \\
\hline A & 1 & $.499^{* *}$ & $.550^{* *}$ & $.421^{* *}$ & $.475^{* *}$ & .153 \\
\hline $\mathrm{B}$ & $.499^{* *}$ & 1 & $.577^{* *}$ & $.466^{* *}$ & .192 & $.583^{* *}$ \\
\hline $\mathrm{C}$ & $.550^{* *}$ & $.577^{* *}$ & 1 & $.563^{* *}$ & .223 & $.436^{* *}$ \\
\hline $\mathrm{D}$ & $.421^{* *}$ & $.466^{* *}$ & $.563^{* *}$ & 1 & .279 & $.551^{* *}$ \\
\hline $\mathrm{E}$ & $.475^{* *}$ & .192 & .223 & .279 & 1 \\
\hline $\mathrm{F}$ & .153 & $.583^{* *}$ & $.436^{* *}$ & $.551^{* *}$ & $.320^{*}$ & 1 \\
\hline **. Correlation is significant at the 0.01 level (2-tailed). & *. Correlation is significant at the 0.05 level (2-tailed). \\
\hline
\end{tabular}

Legend:

A - Customer-oriented democratic (partnership) management style in the company

B - High level of mutual information sharing and cooperation between internal units in serving customers

$\mathrm{C}$ - High degree of cooperation and cohesion of the company with all external stakeholders in the value network in serving customers

internal units in serving customers" and "a high degree of cooperation and cohesion of the company with all external stakeholders in the value network in serving customers" along with the system and rules of customer contacts developed in the company for all the units that come into contact with customers, thus a strong mutual cooperation in the value network and a functional system to process and share information from customer contacts with those company units that need it.

The factor analysis by extraction method Principal Component Analysis with Varimax rotation has revealed two main factors strengthening customer relationships, namely a comprehensively conceived reputation of the company and promotion of customer orientation in the company by the top
D - System and rules of customer contacts developed in the company for all the units that come into contact with customers

E - Senior management participating in negotiations with customers

F - Functional system to process and share information from customer contacts with those company units that need it.

Source: Self-processed

management and SBU (see Table V).

In the opinion of the interviewed managers of chemical companies, the company reputation is dependent especially on the long tradition as a manufacturer of products, long-term positive customer experience with the company, the reputation of a manufacturer of high quality products in accordance with customer requirements, high technical quality and progressiveness of products and consistent standard of product quality parameters in all deliveries.

In their opinion, promoting customer orientation in the company requires a democratic (partnership) customeroriented style of management in the company along with the participation of the top management in negotiations with customers.

TABLE V

ROTATEd COMPONENT Matrix OF THE MAIN COMPONENTS OF THE BENEFITS OF THE COMPANY REPUTATION FOR STRENGTHENING CUSTOMER RELATIONSHIPS

\begin{tabular}{|l|l|l|}
\hline \multicolumn{1}{|c|}{ ASPECTS OF CORPORATE REPUTATION AND CORPORATE CUSTOMER-ORIENTED CULTURE } & COMPONENTS \\
\cline { 2 - 3 } & 1 & 2 \\
\hline Overall quality of the company and a very good reputation in the industry & .677 & .248 \\
\hline Long tradition of the company as a manufacturer of products & .829 & .070 \\
\hline Long-term positive customer experience with the company & .801 & .322 \\
\hline High quality of products in accordance with customer needs & .786 & .390 \\
\hline High technical standard and progressiveness of products & .824 & .327 \\
\hline Consistent standard of product quality parameters in all deliveries & .245 \\
\hline High standard mastery of technological processes in the company & .812 \\
\hline Quality of the customer base - serving the major players in the industry & .687 & .363 \\
\hline Customer-oriented democratic (partnership) management style in the company & .353 \\
\hline High level of mutual information sharing and cooperation between internal units in serving customers & .758 \\
\hline High degree of cooperation and cohesion of the company with all external stakeholders in the value network in serving customers & .151 \\
\hline System and rules of customer contacts developed in the company for all the units that come into contact with customers & .939 \\
\hline Senior management participating in negotiations with customers & .932 \\
\hline Functional system to process and share information from customer contacts with those company units that need it & .638 \\
\hline $\begin{array}{l}\text { Extraction Method: Principal Component Analysis. } \\
\text { Rotation Method: Varimax with Kaiser Normalization. }{ }^{a}\end{array}$ & .546 \\
\hline a. Rotation converged in 3 iterations. & .292 \\
\hline
\end{tabular}




\section{CONCLUSION}

The research showed that all following aspects of the perceived reputation of the company are very important and beneficial for strengthening the relationship with customers, in particular:

- The long tradition and reputation of the company from the customer perspective.

- Long-term positive customer experience with the company.

- High quality products in accordance with customer needs.

- High technical level and progressiveness of products.

- Consistent standard of product quality parameters in all deliveries.

- Quality of customer base - serving the major players in the industry.

The managers perceive the following aspects of the customer-oriented corporate culture as rather beneficial for strengthening customer relationships in the fields of chemical business, namely:

- The democratic style of management in business-oriented companies.

- Senior management involved in key negotiations with customers.

- Sophisticated system of regular contacts with customers.

- Functional system of processing and sharing information from customers within departments of the company.

- High level of awareness and cooperation of internal departments.

- High level of cooperation and interconnection of the company with all external stakeholders in the value network when serving customers.

It turns out that a customer-oriented corporate culture of manufacturers and sophisticated cooperation among all elements of the value network leads and strengthens relationships with customers while helping them to assert themselves better in the challenging market environment.

The findings of this research are very important for improving the managerial style oriented on enhancing quality of customer-oriented corporate culture not only in chemical companies but also in companies of other industries operated on industrial markets. They are very interesting and beneficial for B2B (business to business) marketing because of finding and modifying of different tools for strengthening relationships with customers and increasing their loyalty, too.

\section{ACKNOWLEDGEMENT}

The research was carried out thanks to the financial support provided by the Grant Agency of the Czech Republic under the project No 403/12/1279 "Tools for strengthening the longterm relationships with customers based on integration and cooperation of value network subjects."

\section{REFERENCES}

[1] Brown, T. J., Dacin, P. A., Pratt, M. G. and Whetten D. A., "Identity, intended image, construed image, and reputation: an interdisciplinary framework and suggested terminology," Journal of the Academy of Marketing Science, 2006, vol. 34, no. 2, pp. 99-106. http://dx.doi.org/10.1177/0092070305284969

[2] Keller, K. L., "Brand Strategic Management," Prague: Grada Publishing, 2007.

[3] Capozzi, L., "Corporate reputation: our role in sustaining and building a valuable asset," Journal of Advertising Research, 2005, vol. 45, no. 3, pp. 290-293. http://dx.doi.org/10.1017/S0021849905050324

[4] Keh, H. T., Xie, Y., "Corporate reputation and customer behavioral intentions: The roles of trust, identification and commitment," Industrial Marketing Management, 2009, vol. 38, pp. 732-742.

http://dx.doi.org/10.1016/j.indmarman.2008.02.005

[5] Roberts, P. W. and \& Dowling, G. R., "The value of a firm's corporate reputation: how reputation helps attain and sustain superior profitability," Corporate Reputation Review, 1997, vol. 1, no. 1, pp. 72-76. http://dx.doi.org/10.1057/palgrave.crr.1540020

[6] Roberts, P. W. and \& Dowling, G. R., "Corporate reputation and sustained superior financial performance," Strategic Management Journal, 2002, vol. 23, no. 12, pp. 1077-1093. http://dx.doi.org/10.1002/smj.274

[7] Cretu, A. E. and Brodie, R. J., „The influence of brand image and company reputation where manufacturers market to small firms: A customer value perspective,“ Industrial Marketing Management, 2007, vol. 36, no. 2, pp. 230-240. http://dx.doi.org/10.1016/j.indmarman.2005.08.013

[8] Fombrun, C., "Reputation," Realising Value from the Corporate Image, Harvard Business School Press, Boston, MA, 1996.

[9] Gray, E. R. and Balmer, J. M. T., "Managing Corporate Image and Corporate Reputation," Long Range Planning, 1998, vol. 31, no. 5, pp. 695-702. http://dx.doi.org/10.1016/S0024-6301(98)00074-0

[10] Hansen, H. et al., "Customer perceived value in B-t-B service relationships: Investigating the importance of corporate reputation," Industrial Marketing Management, April 2008, vol. 37, no. 2, pp. 206-217. http://dx.doi.org/10.1016/j.indmarman.2006.09.001

[11] Suh, T., Houston, M. B., "Distinguishing supplier reputation from trust in buyer-supplier relationships," Industrial Marketing Management, July 2010, vol. 39, no. 5, pp.744-751.

http://dx.doi.org/10.1016/j.indmarman.2010.02.013

[12] Kracklauer, H. and Mills, D. Q. and Seifert D., "Collaborative customer relationship management," Springer-Verlag, Berlin, 2010

[13] Čater, T. and Čater, B., "Product and relationship quality influence on customer commitment and loyalty in B2B manufacturing raltionships," 2010, vol. 39, no. 8, pp. 1321-1333.

[14] Chang, S.-H. et al., " Building customer commitment in B2B markets," Industrial Marketing management, 2012, vol. 41, pp. 940-950. http://dx.doi.org/10.1016/j.indmarman.2011.11.026

Hana Lostakova, holds the Prof., MSc. and PHD degree. She is currently a Professor at the University of Pardubice, Czech Republic. She is the Lecturer of the course Strategic management, Introduction to Marketing, Marketing Management, Marketing Research.

She has developed the process of strategic marketing analysis for products aimed at production consumption. Her research is focused on the issues of customer value creation in value network and company performance from the point of view of customers, too. She is the author and co-author of 8 monographs, 216 original scientific papers published in CR and abroad and 34 textbooks.

She has been a member of the Board of the Czech Marketing Society since 1992, a member of the editorial board of journals Marketing \& Communication (CR) since 1995 and Marketing Panorama (SR) since 1999, a member of the scientific board of the FChT at the University of Pardubice since 2006 and a member of the scientific board of the FCHI of VSCHT in Prague since 2008. For many years she has been a member of scientific boards of numerous international conferences. She ranks among the leading experts in B2B marketing not only in the Czech Republic.

Address: University of Pardubice, FCHT, KEMCH, Studentska 97, 53210 Pardubice; Phone: +420 466036516 ;

E-mail: hana.lostakova@upce.cz 